\title{
FINANCING THE DEVELOPMENT OF POOR COMMUNITIES IN THE NORTHERN CAPE OF SOUTH AFRICA - AN ANALYTICAL FRAMEWORK FOR THE STUDY OF LIVESTOCK BANKS
}

\author{
Ana Marr \\ University of Greenwich \\ a.marr@gre.ac.uk
}

September 2008

\begin{abstract}
This paper is part of a major project about the Northern Cape Land Reform and Advocacy (NCLRA) programme being implemented by FARM-Africa* in South Africa. The NCLRA programme had initiated a financial mechanism to help poor communities to get access to finance and training in order to enable them to make better use of their newly-acquired land. One prominent aspect of the programme is the implementation of Livestock Banks, or the use of animals as financial products. The paper provides an analytical framework with which to evaluate the effectiveness of Livestock Banks in the poor communities of the Northern Cape in South Africa. It focuses on the design, implementation and future of Livestock Banks. The paper argues that Livestock Banks need to be reformed and enhanced if they are to continue to play a key role in the goal of creating financial and economic value in Africa, particularly when the primary objective is simultaneously to help reduce poverty.
\end{abstract}

\section{Keywords:}

Microfinance, community development, financial market development, poverty alleviation, innovative finance for the poor

*FARM-Africa (Food \& Agricultural Research Management) is a registered UK charity organisation and a company limited by guarantee in England and Wales no. 01926828.

\footnotetext{
Dr Ana Marr is Programme Area Director of the International Business and Economics Department at the Business School, and Senior Research Fellow at the Natural Resources Institute, University of Greenwich, UK.
} 


\section{BACKGROUND}

Microfinance has revolutionised the financial landscape and become a potentially powerful tool for the reduction of poverty worldwide. With innovative products and institutions, microfinance has expanded the frontiers of financial markets to include the millions of poorly-resourced households who were previously left to fend for themselves (Armendáriz \& Morduch, 2005). By working in groups and extending small-scale financial products, microfinance has helped mitigate the information asymmetries and high transaction costs usually associated with lending to low-income populations, generally perceived as risky clients.

The vast literature on microfinance practice has focused on cash transactions with the target population in need of financial services (Hulme \& Mosley, 1996; Brau \& Woller, 2004; Cull, Kunt \& Morduch, 2007). What has been neglected is the study of in-kind microfinance whereby transactions are primarily based on livestock. This paper aims at filling this gap and contributing towards a better conceptual understanding of cashless microfinance. While the general theoretical framework of group-lending (that generates peer monitoring and reduces default risks) applies to in-kind microfinance, livestock banking needs to be specifically studied in relation to the quantity and quality of the livestock and other supportive mechanisms for the system to survive.

The present paper offers an alternative analytical framework based on the empirical working of a charity organisation in the Northern Cape of South Africa. Thus, the following section presents the original model put in place in South Africa and highlights the key elements involved in the so-called Livestock Bank. Section 4 describes the research methodology and the findings encountered during field research. Section 5 proposes an improved Livestock Bank model, while Section 6 concludes the paper with some recommendations.

\section{DESCRIPTION OF THE ORIGINAL MODEL}

FARM-Africa South Africa (FARM-SA), a UK-funded charity organisation, has specialised in innovative agricultural development programmes with poor communities in South Africa. Its Northern Cape Land Reform and Advocacy programme began in 2004, aiming at reaching twenty sites in the Northern Cape Province over a four-year period. The first part of the research into the impacts of the NCLRA programme - the findings of which are the core of this paper - took place during an intensive period of fieldwork during September and October 2006. Primary data was gathered by the author through individual semi-structured interviews with beneficiaries, focus group discussions with communities, field observation of livestock and infrastructure environment, and interviews with key stakeholders such as government officials, banks, agricultural cooperatives and private investors. Complementary information was based on internal institutional reports and existing literature.

Prior to presenting the analysis of our research findings, this section aims at establishing what constitutes the original model for present-day Livestock Banks (LB). The diagram below provides a graphic representation of this original model, where the goal has been "to increase livestock ownership amongst the poorest members of land reform groups so that they can secure incomegenerating assets, strengthen rights of access to their communal land and improve their livelihoods" (Festus \& Joseph, 2006:10). It is important to note that a key objective has been that of enhancing ownership of livestock and hence the emphasis seems to be placed on 
increasing the quantity of animals owned by beneficiaries - at least in theory. This issue will be brought up again when we discuss what happens in practice and then when an improved model is suggested in Section 5.

There are five key elements that feed into the workings of LBs as shown in FIGURE 1. These are: (1) Seed capital; (2) Training; (3) Self-finance; (4) Planning; and (5) a pre-determined selection criteria. In all elements, FARM-SA has either a direct input or a facilitation role to put in place mechanisms for programme participants to make collective decisions. In the case of seed capital and training, for example, FARM-SA has allocated resources to provide direct inputs in the form of cash (to help set up LBs) and training in financial management, animal and veld management and organisational development.

Conceptually, there is a pre-determined criterion by which participants should be selected amongst the poorest of the poor and the socially excluded, and should show commitment and interest in the programme. Once participants are selected, FARM-SA, partly as a result of the training in organisational development, strengthens their ability to work in groups and facilitates the setting up of self-generated sources of finance, such as the establishment of LB membership fees and monthly contributions, which are planned to help towards the care of livestock and to self-sustain the banks. The planning of related activities is primarily facilitated by FARM-SA through the Participatory Land Use Planning, whereby group participants collectively make decisions on carrying capacity, type of livestock to invest the seed capital in, type of livestock care and other potential activities to be initiated by the group.

Loan contracts are another important initiative by FARM-SA. Once the NGO hands over the seed capital to a particular group of participants, the group invests the capital in acquiring livestock. The livestock is then on-lent to individual LB members and loan contracts are signed between the group and each individual member. According to internal reports and discussions with staff, four key contract features can be identified: methodology, interest rate, loan duration, and repayment frequency.

On the methodology and in line with theoretical principles, there are two ways of lending livestock: individually and in groups. When lending is on an individual basis, it is said that loans can be made of between eight and 10 ewes per member. When in groups, 40 ewes are expected to be lent to a group of five members. This amounts to interest rates of between $15 \%$ and $20 \%$ per annum, for loan duration of two years. Loan repayment is made in a number of 6-7 month-old offspring.

The management structure that sustains the banks is conceptualised as formed by two subcommittees. One is the so-called Revolving Fund sub-committee, which is responsible for the financial management, monitoring, accounting and book keeping of cash. The other one is called Livestock Bank sub-committee and deals with operational decisions regarding animal and veld management including monitoring of livestock care, recording of events and planning of activities.

The final feature of the LB model is the Participatory Monitoring and Evaluation step. This is designed to start after LBs are in full operation and it involves FARM-SA staff monitoring the working of LBs with full participation of group members, particularly those of the subcommittees. In theory, monthly reports are fed into members' general meetings in order to make collective decisions on issues arising from the monitoring and evaluation process and follow-up implementation actions can be taken. 
Aim: To increase livestock ownership amongst the poorest members of land reform groups so that they can secure income-generating assets, strengthen rights of access to their communal land and improve their livelihoods.

\section{KEY ELEMENTS}

\begin{tabular}{|l|l|l|}
\hline Seed capital: & $\begin{array}{l}\text { Training: } \\
\text { Amount } \\
\text { Starting date: } 2005 \\
\text { No. projects: about } 20\end{array}$ \\
\hline $\begin{array}{l}\text { Financial management } \\
\text { Animal and veld management } \\
\text { Organisational development }\end{array}$ \\
$\begin{array}{l}\text { Poorest of poor } \\
\text { Socially excluded } \\
\text { Commitment and interest }\end{array}$
\end{tabular}

\section{LOAN CONTRACT}

Methodology:

- Individual: 8-10 ewes (sheep) per member

- $\quad$ Group: 40 ewes to a group of 5 members

Interest rate:

- Individual: 3-4 lambs over two years, i.e. $20 \%$ per annum.

- Group: 12 lambs over two years, i.e. $15 \%$ per annum

Loan duration:

- Two years maximum.

Repayment frequency:

- $\quad$ After each lambing season, e.g. yearly, when lambs are 6-7 months old.

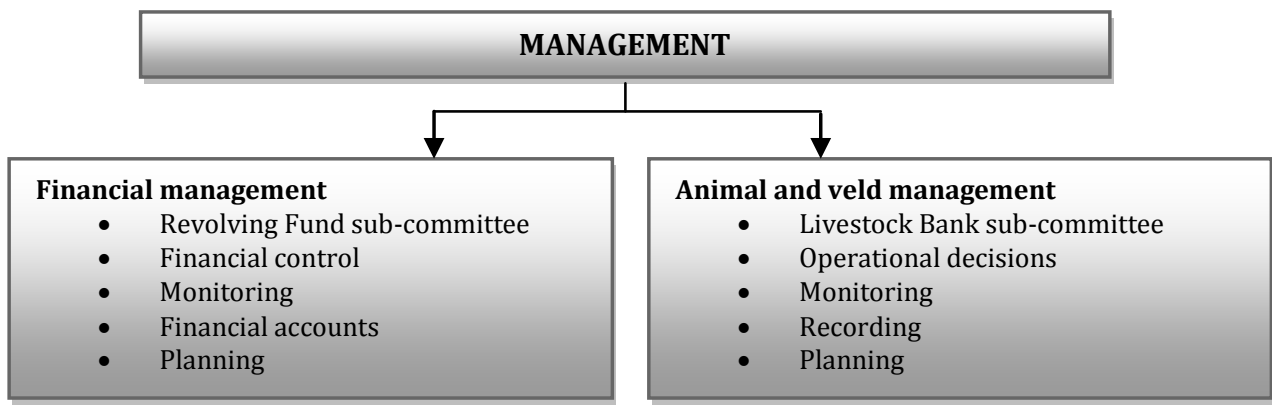

\section{PARTICIPATORY MONITORING AND EVALUATION}

- Monitoring by sub-committees

- Monthly report back to members' general meetings

- Progress reports

- Follow-up implementation

\section{FIGURE 1: Livestock Bank Model (Original design)}

Source: Author 


\section{IMPLEMENTATION PHASE - RESEARCH METHODOLOGY, FINDINGS AND COMMENTS}

A major part of the research constituted an investigation of programme progress during the implementation phase thus far. To this end, a working methodology was employed, which included (1) Fieldwork in 10 out of the 12 existing programme sites; (2) Focus group presentations and discussion; (3) Individual semi-structured interviews with beneficiaries; (4) Individual semi-structured interviews with officials of Department of Agriculture, Municipalities, Cooperatives, Land Bank; (5) Review of statistics and training manuals; and (6) Review of internal reports and other relevant literature. A total of 124 individuals were interviewed and/or participated in the investigation.

Research procedures for the qualitative analysis included: (a) A pre-determined list of topics to be discussed during interviews and focus groups. These topics were closely linked to the programme objectives in order to assess progress in achieving goals, e.g. extent and quality of training; (b) Information obtained during interviews and focus group discussions was recorded in pre-coded sheets; information was numerical, categorical and expressed in written comments; (c) Manually-recorded information was inputted into computer programmes immediately after fieldwork; (d) Brief analysis of information was carried out on the same day of collection and prior to following fieldwork in order to help inform further interviews/discussions; and (e) Final and fuller analysis was undertaken at the end of fieldwork, taking into account the totality of information gathered.

\subsection{Key research findings}

\subsubsection{General comments}

In general terms, progress with the implementation of Livestock Banks has been satisfactory, despite given constraints on the FARM-SA programme, such as (1) Limited funds; (2) Shorter timeframe for Phase 2 programme sites (half of them) as compared to that of Phase 1; and (3) The need to utilise funds within timeframe, leading to incongruence between livestock cycles and LB implementation, e.g. livestock purchases were carried out when prices were at their highest due to the need to utilise funds at that particular point in time.

An extraordinary strength of the existing LB concept is its flexibility and adaptability to local conditions. In practice, the exact way in which LBs have been established has involved the introduction of a number of innovations, with the implicit aim to adapt the original model to the realities of participating communities. This has brought about important new ways to deal with LBs, some of which the research team recommends preserving, while others might not be so desirable to keep. Overall, the issue of flexibility must be maintained.

Issues of sustainability and replicability, on the other hand, have not been tackled consistently and comprehensively although staff members are aware of these and are trying to put in place ad-hoc ways to achieve this. The research recommendations are explicitly targeted at assisting the programme in this area-see Section 5.

More specific comments and findings of the implementation phase are dealt with in the rest of this section. 


\subsubsection{Selection criteria}

TABLE 1 shows that the current total number of programme beneficiaries is 463 , and a quarter of them are female. It is also interesting to note that only $22.5 \%$ of all beneficiaries are members of LBs, which means that just over a hundred households are direct beneficiaries of livestock acquisition. In theory, a second round of beneficiaries are expected to benefit from LBs once the first round of borrowers pay back their debt. In practice, this could be achieved by accelerating the process of inclusion into the LB scheme, as suggested by the improved LB model and in the recommendations of Section 5 .

TABLE 1: Number of beneficiaries by gender, 2006

\begin{tabular}{|c|c|c|c|c|c|}
\hline \multirow{2}{*}{\multicolumn{2}{|c|}{$\begin{array}{c}\text { Land Reform group } \\
\text { Phase 2 (1) }\end{array}$}} & \multicolumn{4}{|c|}{ Beneficiaries } \\
\hline & & \multirow{2}{*}{$\frac{\text { Male }}{100}$} & \multirow{2}{*}{$\begin{array}{c}\text { Female } \\
28\end{array}$} & \multirow{2}{*}{$\begin{array}{c}\text { Total } \\
128\end{array}$} & \multirow{2}{*}{$\frac{\angle B}{10}$} \\
\hline BLOCUSO Trust & Soverby & & & & \\
\hline & Curriescamp & & & & \\
\hline & Bloemsmond & & & & \\
\hline De Banken Farmers & & 11 & 4 & 15 & 11 \\
\hline Beeshoek Trust & & 21 & 4 & 25 & 11 \\
\hline Campbell Livestock Farmers & & 40 & 9 & 49 & 10 \\
\hline Barkley West Small Farmers & & 60 & 5 & 65 & 6 \\
\hline Kopano Trust & & 11 & 12 & 23 & 0 \\
\hline \multicolumn{6}{|c|}{ Phase 2 (2) } \\
\hline Brandvlei Emerging Farmers & & 26 & 5 & 31 & 7 \\
\hline Van Wyksvlei Farmers & & 19 & 4 & 23 & 6 \\
\hline Lennertsville Farmers & & 9 & 2 & 11 & 6 \\
\hline Schmidsdrift Farmers & & 49 & 15 & 64 & 13 \\
\hline Laughing Waters & & 7 & 2 & 9 & 9 \\
\hline Ganspan Female Farmers & & 0 & 20 & 20 & 15 \\
\hline TOTAL & & 353 & 110 & 463 & 104 \\
\hline
\end{tabular}

Source: Adapted from FARM-Africa (South Africa) "Overview Phase 2" information emailed to the research author in October 2006. Figures for the final column were provided during field visits.

Similarly, a qualitative assessment of the wealth ranking of LB beneficiaries carried out during field visits revealed that there was a wider range of beneficiaries than anticipated by the original model. In other words, beneficiaries range from the poorest of the poor to the better-off within communities. This mix does not seem to be problematic, as the economically-active poor appear to adapt faster to the LBs.

Although the economically-active poor might be an acceptable entry point for LB operations, mechanisms to include the poorest need to be put in place as suggested in the following sections. 


\subsubsection{Training}

Training is an important and essential element for the well-functioning of LBs. FARM-SA training in financial management, animal and veld management, and organisational development is very appreciated by beneficiaries and it is often quoted as the most salient benefit from participating in the FARM-SA programme.

From field visits to the majority of participating communities, it became evident that training had improved beneficiaries' skills dramatically, such as in the case of participants with no prior education or very low levels and significantly for a large number of beneficiaries. As an outstanding example, the treasurer of one project remarked: "FARM-Africa has made me intelligent." He shows the research team the type of book keeping that he used to do before FARM-SA training and the record booking of today - a much improved version. The participant was evidently much more capable of keeping financial accounts in an orderly fashion, and the boost to his personal confidence was shown in his glowing face and pride in his work.

In general, training in financial management has been focused on members of the Revolving Fund sub-committees only. This means that 5-6 people of each project (some as large as about 130 members) are the only beneficiaries of financial training. There is hence a need to develop strategies to involve other members.

It is important to note that training has not been restricted to financial matters: it has covered other issues including how to handle meeting procedures, participatory land use planning, participatory community empowerment, livestock management, conflict resolution and leadership skills.

In general terms, TABLE 2 presents the various types of training modules and the current total number of beneficiaries by gender. Training in animal and veld management has been more widely available to participants, while financial management, as mentioned before, has been more focused on raising the skills of sub-committee members. The representation of female beneficiaries participating in training courses is higher than the overall percentage of female project members - i.e. around $35 \%$ compared to about $25 \%$. This shows that FARM-SA has made special efforts to include women amongst the direct beneficiaries of training and skill development.

TABLE 2: Number of beneficiaries of training modules, 2006

\begin{tabular}{llcc}
\hline & Training & Male & Female \\
\hline Rights \& Constitutions & & 78 & 49 \\
Organisational Development & & 84 & 49 \\
Financial Management & & 54 & 32 \\
& Dairy Goats Management & & \\
& Dorper Goat Management & & \\
Natural Resource Management & Boer Goat Management & 103 & 55 \\
& Vegetable Production & & \\
& Veld Management & & \\
\hline
\end{tabular}

Source: FARM-SA, Information emailed to author in October 2006 
There are however some challenges to a more effective delivery of training modules. These include (1) Differences in education/skill levels among members of the sub-committees; (2) Differences in languages; and (3) Distance between projects. Some of these challenges can be addressed during the Participatory Monitoring and Evaluation process and with the introduction of some modification to the training procedure.

\subsubsection{Self-finance}

During implementation, LB beneficiaries are given the faculty to determine the level of monthly contribution that they would require members to make towards the sustainability of banks. This level varies across participating communities between R25 and R60 per month. Monthly contributions in turn usually cover expenses for animal medicine and other inputs. In some cases it covers all or part of shepherds' salaries. In general, there are no penalties for late payments of contributions, but in one case the penalty is $100 \%$.

TABLE 3 shows the financial situation of LBs at June 2006. It should be noted at this point that the difference between Phase 2.1 and Phase 2.2 participating communities is that the former started operations in 2004 while the latter did so in 2005 . The difference in starting dates is hence reflected, primarily, in the varying accumulated monthly contributions, payment of shepherd wages, and livestock sales.

TABLE 3: LB financial situation at June 2006 (Rand)

\begin{tabular}{|c|c|c|c|c|c|c|c|c|}
\hline \multirow[b]{2}{*}{ PHASE 2.1} & \multicolumn{4}{|c|}{ INCOME } & \multicolumn{3}{|c|}{ EXPENDITURE } & \multirow[t]{2}{*}{$\begin{array}{l}\text { PROFITI } \\
\text { LOSS }\end{array}$} \\
\hline & $\frac{1}{\frac{1}{2}}$ & 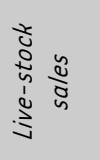 & 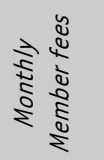 & \begin{tabular}{ll}
$\stackrel{1}{s}$ & 0 \\
$\frac{1}{d}$ & 0 \\
\multirow{2}{*}{} & 0 \\
0 & 0
\end{tabular} & 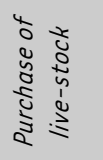 & 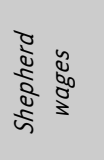 & 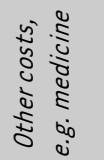 & \\
\hline Barkley West & 50000 & 2377 & 3550 & & 31493 & 8420 & 9280 & 6733 \\
\hline Beeshoek & 50000 & 7138 & 3314 & 1789 & 42262 & - & 10846 & 9133 \\
\hline Blocuso & 140000 & - & 2100 & 5166 & 36652 & - & 3194 & 107420 \\
\hline Campbell & 50000 & 2131 & 7811 & 3208 & 44346 & 6400 & 6245 & 6158 \\
\hline De Banken & 50000 & 11529 & 2390 & 11373 & 40731 & - & 12079 & 22482 \\
\hline Kopano & 30000 & & & & & & & \\
\hline \multicolumn{9}{|l|}{ PHASE 2.2} \\
\hline Brandvlei & 50000 & - & 1220 & 98 & 39900 & - & 1019 & 10399 \\
\hline Ganspan & 30000 & - & 1415 & 179 & 22800 & 200 & 1440 & 7154 \\
\hline Laughing Waters & 30000 & - & 1690 & 187 & 23340 & - & 3420 & 5117 \\
\hline Lennertsville & 50000 & & 1440 & 530 & 39904 & - & 2179 & 9887 \\
\hline Schmidtsdrift & 120000 & & 1400 & 1652 & 40950 & - & 2144 & 79958 \\
\hline Van Wyksvlei & 50000 & & 1690 & 3 & 34560 & 1050 & 2136 & 13947 \\
\hline
\end{tabular}

Source: Fieldwork in South Africa, September 2006

By June 2006, all participating communities had generated profits. Existing cash is kept in two types of bank accounts - current and investment - and withdrawals need the signature of a 
FARM-SA member and 1-2 LB members. This is good practice that needs to be maintained in the future.

However, there are at present no contingency funds or reserves for unforeseen events such as natural disasters, and hence LBs are currently vulnerable to sudden shocks and the potential loss of accumulated profits.

In addition to the establishment of Livestock Banks, some communities have invested part of their revolving funds in other projects such as the purchasing of dairy goats, cattle, tools, vehicles and other agricultural inputs. These are listed in TABLE 4.

TABLE 4: Type of projects initiated by programme participants

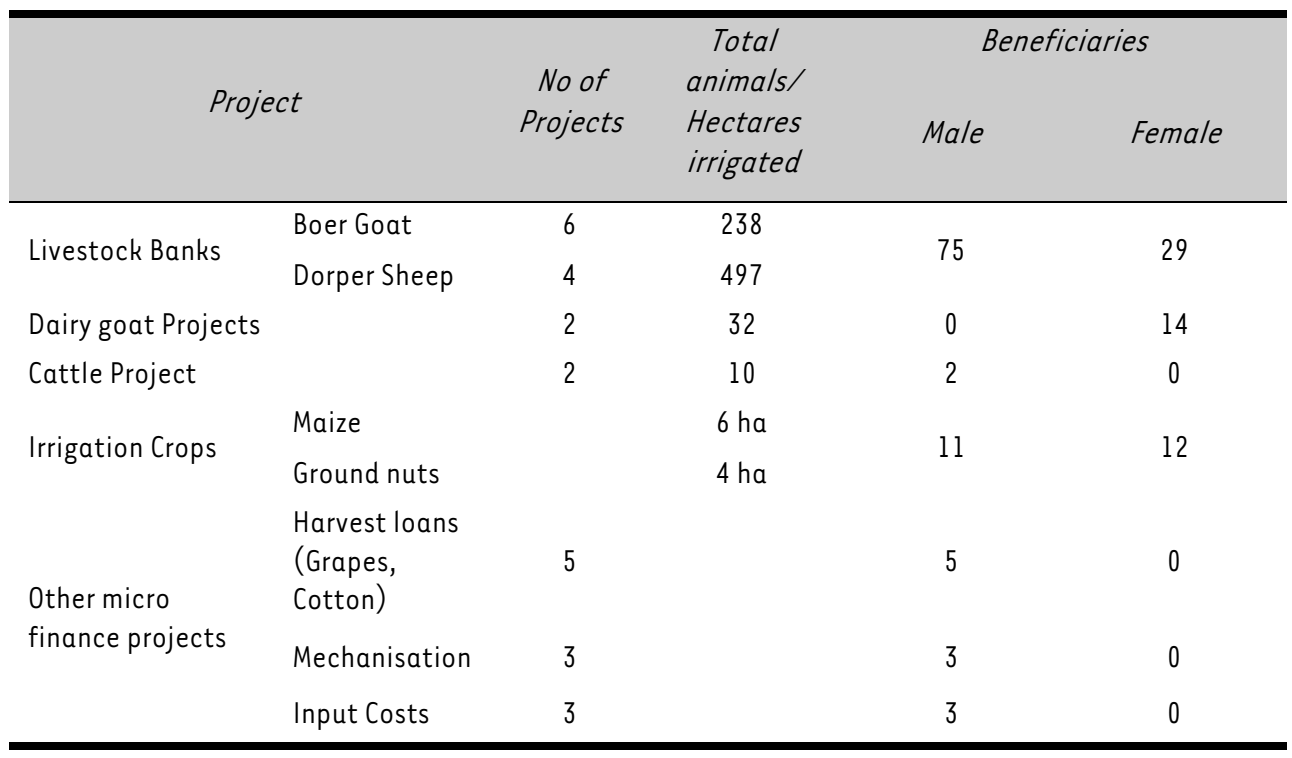

Source: FARM-SA, Information emailed to author in October 2006

As projects outside Livestock Banks are in general minor, they will not be looked at in detail in this paper. It should be recognised, however, that some of these projects are working towards the self-financial situation of LBs.

\subsubsection{External sources of finance and training}

FARM-SA is aware of potential sources of finance and training, in terms of the type of institutions available. Although some attempt has been made to link with those institutions, results have not been particularly fruitful and relationships need to be developed more fully. See recommendations in Section 4.

\subsubsection{Loan contract}

There have been important innovations in the original loan contract during the implementation phase. The most salient innovation is the acquisition of rams - not just ewes - when operating Livestock Banks. This has happened organically when working with LBs in practice and realising that the quality of offspring could be improved by acquiring good-quality rams. 
The acquisition of rams, in turn, has occurred both informally and formally. Informally, participating communities have acquired rams through donations from commercial farmers (who were also the sellers of ewes to these communities) and through purchases from available sources such as breeder associations. Formally, a new programme was established in some participating communities, which is named "Livestock Improvement Programme." The programme is explicitly set up to purchase good-quality rams by making use of part of the seed capital provided to communities by FARM-SA.

During field visits to LBs, it became evident that the quality of livestock differed significantly partly due to the quality of ewes bought in the initial purchase and partly due to the lack of good-quality rams available to communities. It is hence indispensable to build on the important innovations introduced by FARM-SA and improved the original LB model according - this is developed in Section 3 and 4.

The current livestock situation is presented in TABLE 5. It can be seen that the birth rate is satisfactory and seems to be the result of a good year in terms of weather and natural resources. The loss rate appears to be within the range of $4 \%-20 \%$, which is not unacceptable compared to the estimated average rate in commercial farms of $15 \%$ in the Northern Cape. Sales of animals have occurred in the Phase 2.1 projects that started in 2004 while Phase 2.2 ones are yet to consider selling livestock at this stage.

TABLE 5: Livestock situation, September 2006

\begin{tabular}{|c|c|c|c|c|c|c|}
\hline PHASE 2.1 & $\begin{array}{c}\text { Livestock } \\
\text { Bank } \\
\text { members }\end{array}$ & $\begin{array}{c}\text { Livestock } \\
\text { initial } \\
\text { purchase }\end{array}$ & Births & Losses & Sales & $\begin{array}{c}\text { Current } \\
\text { Stock }\end{array}$ \\
\hline Barkley West & 6 & 62 & 50 & 22 & 7 & 83 \\
\hline Beeshoek & 11 & 90 & 98 & 8 & 23 & 157 \\
\hline Blocuso & 10 & 15 & 21 & 4 & 0 & 32 \\
\hline Campbell & 10 & 104 & 110 & 40 & 9 & 165 \\
\hline De Banken & 11 & 73 & 145 & 12 & 69 & 137 \\
\hline \multicolumn{7}{|l|}{ Kopano } \\
\hline \multicolumn{7}{|l|}{ Phase 2.2} \\
\hline Brandvlei & 7 & 70 & 35 & 5 & 0 & 100 \\
\hline Ganspan & 15 & 10 & 6 & 0 & 0 & 16 \\
\hline Laughing Waters & 9 & 22 & 19 & 6 & 0 & 35 \\
\hline Lennertsville & 6 & 62 & 36 & 7 & 0 & 91 \\
\hline Schmidtsdrift & 13 & 85 & 52 & 6 & 0 & 131 \\
\hline Van Wyksvlei & 6 & 64 & 16 & 3 & 0 & 77 \\
\hline
\end{tabular}

Source: Researcher's fieldwork in South Africa, September 2006

Regarding the methodology for lending, there is some lack of clarity about whether loans are 
liable to the individual or to the collective group of LB members. As mentioned in Section 2, contracts are signed with the individual borrower but, in practice, in many cases all animals are taken care of by the group as a whole. Although most communities appear to be content with this type of arrangement, the lines of responsibility for loan repayment are not completely clear, which may lead to increasing conflict and disillusion by members if problems of non-repayment arise.

There is also some inconsistency in the way livestock is identified in practice (by ear-tags or tattoos). In most cases livestock is identified as belonging to the LB group but there are cases where livestock is not identified as belonging to specific individuals within the LB group. Lack of consistency in this area could also potentially create difficulties in determining loan liability in case of non-repayment.

It is interesting to note that the care of livestock is being implemented in various ways: (1) Collectively with the contracting of a shepherd; (2) By individuals in individual camps; and (3) Collectively by the LB beneficiaries themselves. TABL $\boldsymbol{6} 6$ shows the advantages and disadvantages in each of these types of livestock care.

TABLE 6: Advantages and disadvantages of LB implementation of livestock care

\begin{tabular}{|c|c|c|}
\hline & ADVANTAGES & DISADVANTAGES \\
\hline $\begin{array}{l}\text { COMMUNAL CARE } \\
\text { (with shepherd) }\end{array}$ & $\begin{array}{l}\text { Animal management } \\
\text { - Allows beneficiaries to } \\
\text { dedicate time to other econ } \\
\text { activities because of shepherd } \\
\text { taking charge of animals } \\
\text { - Economies of scale } \\
\text { - Risk pooling and sharing } \\
\text { - High animal quality if shepherd } \\
\text { is good } \\
\text { Financia/ management } \\
\text { - Cost-effective if shepherd is } \\
\text { good and shares knowledge } \\
\text { with LB beneficiaries }\end{array}$ & $\begin{array}{l}\text { Financial management } \\
\text { - Financial cost of shepherd } \\
\text { (ZAR600) } \\
\text { - Potential problem with } \\
\text { accommodation of shepherd in } \\
\text { commonage } \\
\text { Animal management } \\
\text { - Potential problems with } \\
\text { management of animals by } \\
\text { shepherd } \\
\text { - Potential disincentive for } \\
\text { beneficiaries to farm } \\
\text { Organisation management } \\
\text { - Potential conflicts within the } \\
\text { group due to poor management of } \\
\text { shepherd }\end{array}$ \\
\hline INDIVIDUAL CARE & $\begin{array}{l}\text { Animal management } \\
\text { - Good managers could share } \\
\text { knowledge with others - } \\
\text { healthy competition among } \\
\text { them } \\
\text { - Sense of ownership } \\
\text { Financial management } \\
\text { - Flexible repayment, even } \\
\text { before due time. }\end{array}$ & $\begin{array}{l}\quad \text { Financial management } \\
\text { - Individual bears full risk } \\
\text { - Lack of collateral, lack of group } \\
\text { joint-responsibility/liability } \\
\text { - Higher non-repayment risk } \\
\text { Anima/ management } \\
\text { - Diverse/uneven animal quality } \\
\text { which could be problematic }\end{array}$ \\
\hline
\end{tabular}


- Potential for quicker turnover of animals

COMMUNAL CARE (by beneficiaries themselves)
Financial management

- In practice, beneficiaries may become jointly responsible for lack of repayment by some

\section{Animal management}

- Beneficiaries can learn from experienced members if all are involved in animal care

\section{Animal management}

- All animals are affected if camp is badly chosen, e.g. vulnerable to theft, loss, damage

\section{Organisational management}

- Potential conflict due to freeriding (not all members contribute the same), disagreements, etc.

- Risk sharing

Source: Researcher's fieldwork in South Africa, September 2006

The major advantage of communal versus individual care is that the former permits pooling of risks and economies of scale, leading to lower risks and higher benefits if participants learn from each other's experiences. The advantages of individual care are that it promotes enhanced sense of ownership, flexible loan repayment (even before due time) and the potential for quicker turnover of animals.

There are however disadvantages in all types of livestock care. The primary disadvantage in communal care is the increased vulnerability of all animals being affected if the camp is badly chosen and the performance of shepherds is poor. This may lead to potential conflict among members due to disagreements about how to manage shepherds, free-riding of some group members, and the consequent financial implications to LBs. The main disadvantages of individual care are the higher risks involved and the potential for very unequal quality of livestock care, which may lead to collective problems.

Another important area in loan contracts is the treatment of cases of non-repayment. During focus group discussions and individual interviews, it was revealed that there is no systematic way of dealing with possible late or non-repayment of loans. When asked, beneficiaries suggested ways on the spot but they do not seem to have thought about it and have not discussed these issues in meetings. However, there are some measures to help avoid nonrepayment, which have been put in place by FARM-SA or initiated by participants themselves. These include: (1) Regular monitoring of livestock condition, primarily by sub-committee members; (2) Sale of unproductive ewes and purchase of productive ones instead; (3) Purchase of better-quality rams; and (4) Fund-raising activities to allow members to pay their monthly contributions in time. These are all-important mechanisms to help avoid non-repayment and show the 'prevention' quality aspect of LB operations. This good practice needs to be maintained.

\subsubsection{Management}

In theory, as mentioned in Section 2, there are two main sub-committees dealing with LB issues: (1) the Revolving Fund sub-committee; and (2) the Livestock Bank sub-committee.

In practice, in a large number of participating communities these two sub-committees have effectively become one, partly due to the fact that both sub-committees are composed of the same members, and because most of the Revolving Fund is used in the implementation of the Livestock Bank. Management structures can hence be simplified and improved for all programme 
communities, as suggested in the recommendations in Section 4.

\subsubsection{Participatory monitoring and evaluation}

The consistency of the participatory monitoring and evaluation process can be constrained, in practice, by: (1) Long distance to and between projects; (2) Limited time and resources.

In general, the process of participatory monitoring and evaluation is performing well but it may need to re-focus in order to aim for greater impact, sustainability and replicability of the Livestock Bank model, as suggested in the following sections.

\section{PROPOSED REVISED LIVESTOCK BANK MODEL}

Building on innovations already introduced by FARM-SA and on observations made during fieldwork, the author proposes a revised Livestock Bank model, which is graphically represented in FIGURE 2 and explained systematically in the detailed set of recommendations advanced in Section 5 .

In this section, we briefly highlight the main elements of the revised model that differ from the original LB model. There are three new elements to the model: (1) External finance; (2) External training; and (3) Good practice and lesson learning. Although FARM-SA has been exploring sources of external finance and training, these have not yet been formally recognised as key elements of the LB model. The revised model makes explicit the important contribution of these key elements and spells out the institutions and programme areas where external finance and training can be accessed, including the requirement of proven evidence from beneficiaries that they have made contact with external institutions and the progress achieved.

The third very important new element is that of Good Practice and Lesson Learning. It is strongly recommended that FARM-SA should aim for the attainment of good practice in Livestock Bank design and implementation by establishing a systematic process that would:

- Track changes - as with the innovations already introduced.

- Synthesise amendments.

- Identify good and bad practices.

- Record amendments: what, why and how.

- Enable discussion of results among FARM-SA staff and record lessons learnt through a process of regular interactions.

On the design of loan contracts, more clarity has been introduced in all aspects, particularly with regard to the methodology and repayment frequency. In addition, two new elements have been incorporated: penalties for non-repayment and contingency funds.

Management structures, on the other hand, have been allowed to be simpler in order to permit enhanced transparency and accountability. The Participatory Monitoring and Evaluation process, meanwhile, is expected to emphasise tasks leading to the sustainability and replicability of LBs. 
Aim: Enhance livestock productivity, i.e. quantity and quality of stock; create and increase productive assets amongst the poor members of land reform groups; act as the engine for the initiation of other income-generating activities; and improve beneficiaries' livelihoods

\section{KEY ELEMENTS}

\begin{tabular}{|c|c|c|}
\hline Seed capital & $\begin{array}{l}\text { Training: } \\
\text { Financial management } \\
\text { Animal and veld management } \\
\text { Organisational development } \\
\text { Peer-training and peer-auditing }\end{array}$ & $\begin{array}{l}\text { Self-finance: } \\
\text { Membership fee: R100 } \\
\text { Monthly contribution: R25-60. } \\
\text { Contingency fund } \\
\text { Voluntary savings }\end{array}$ \\
\hline $\begin{array}{l}\text { External training } \\
\text { DoA, Cooperatives, } \\
\text { Commercial farmers } \\
\text { Proven evidence of } \\
\text { established contact } \\
\text { by beneficiaries }\end{array}$ & $\begin{array}{c}\text { Livestock } \\
\text { Bank }\end{array}$ & $\begin{array}{l}\text { External finance: } \\
\text { Cooperatives, e.g. GWK } \\
\text { DoA: MAFISA, Food Security, } \\
\text { Livestock Improvement } \\
\text { Programme } \\
\text { LandCare, CASP } \\
\text { Land Bank } \\
\text { Municipalities }\end{array}$ \\
\hline $\begin{array}{l}\text { Selection criteria: } \\
\text { Entry point: } \\
\text { economically-active } \\
\text { poor. Include the } \\
\text { poorest in skill building } \\
\text { (training) and learning- } \\
\text { by-doing (by working } \\
\text { with community } \\
\text { members on the land). }\end{array}$ & $\begin{array}{l}\text { Good Practice and } \\
\text { Lesson Learning } \\
\text { Synthesis and } \\
\text { recording of } \\
\text { changes } \\
\text { Identification of } \\
\text { good/bad practice } \\
\text { and lessons learnt }\end{array}$ & $\begin{array}{l}\text { Planning: } \\
\text { PLUP guided by key basic studies: } \\
\text { Business viability } \\
\text { Market research } \\
\text { Impact study }\end{array}$ \\
\hline
\end{tabular}

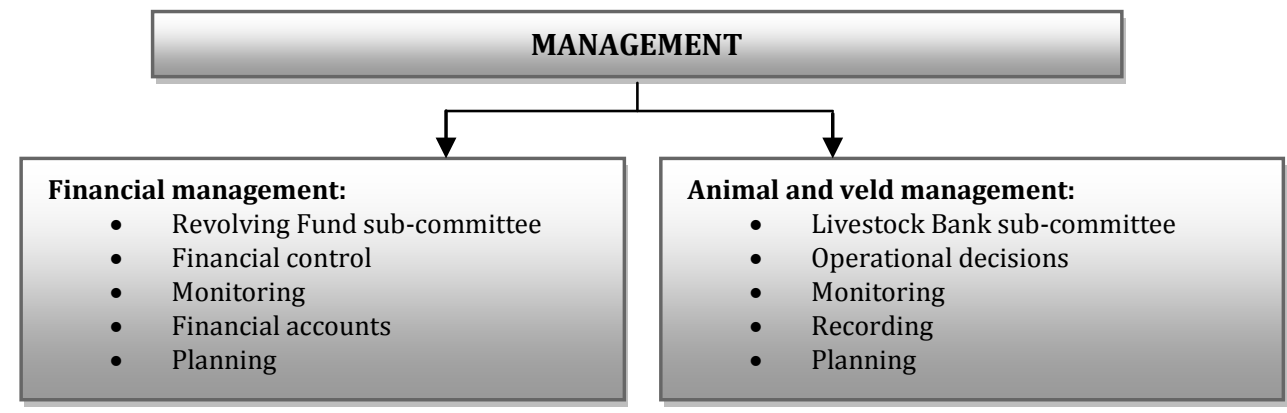




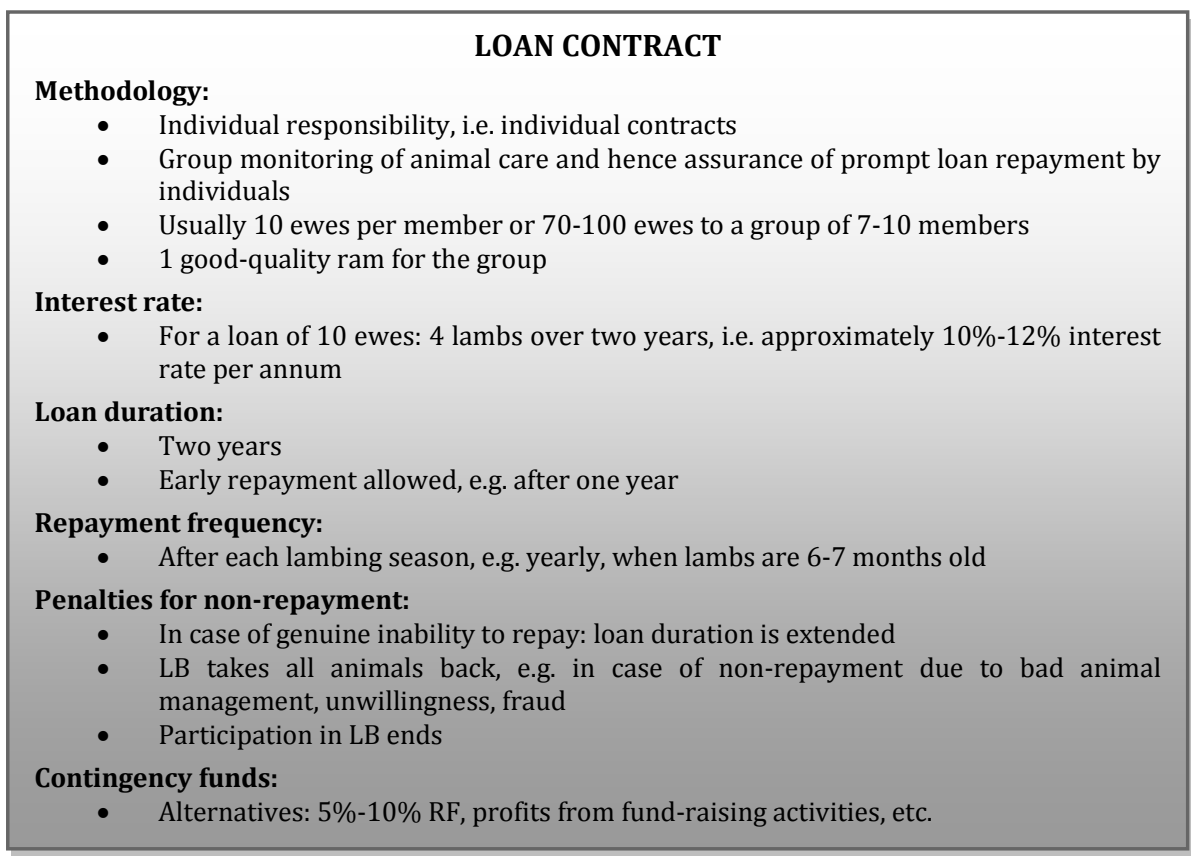

\section{PARTICIPATORY MONITORING AND EVALUATION}

Emphasise tasks leading to sustainability and replicability of LBs

- Monitoring by sub-committees

- Monthly report back to members' general meetings

- $\quad$ Progress reports

- Follow-up implementation

\section{FIGURE 2: Livestock Bank Model (MTR proposed amendments)}

Source: Author

\section{CONCLUSIONS AND RECOMMENDATIONS}

The underlying rationale for the set of recommendations is to advance a proposal for an improved Livestock Bank model, which could be adopted partly in the short term and fully in the setting up of new programmes by local stakeholders in South Africa.

The full list of research recommendations in relation to Livestock Banks are discussed in this section. They tackle primarily issues of design, training, external finance, management structures, information systems, and promotion of LBs.

\subsection{Short-term recommendations}

In the short term, it is recommended the implementation of essential adjustments to the existing LB model. 


\subsubsection{Cost-effectiveness of livestock acquisition}

It is important that the programme produces a clear assessment of the costs involved in the acquisition of rams - as it is being implemented in practice at present - and evaluates the costeffectiveness of the different options available. This will be an essential first step towards adopting the new design of the LB model that is developed in Section 5.2.

As mentioned before, participating communities have come to the realisation that they need to acquire rams in order to improve the quality of their animals. In practice, rams have been acquired through donations or via purchases from public and private agents. This process occurs organically or through the establishment of the "Livestock Improvement Programme." In both cases, what is suggested is to:

- Document the experience of acquisition of rams by participating communities, e.g. donations, purchases, etc.

- Record price, quality and characteristics of acquired rams.

- Compare the cost involved in various options: e.g. donation, purchase from government or private, etc.

- Analyse and document the relative cost-effectiveness of each option.

This assessment will help inform FARM-SA and aid them in making decisions on whether to implement a formal new LB model that includes the purchasing of rams as well as ewes, how, and at what point in time in the future.

\subsubsection{Contingency funds and loan contracts}

One essential element to the LB design that is currently lacking is contingency funds. It is hence advisable that the programme institutes a contingency fund in all participating communities, which would cover for unforeseen eventualities such as natural disasters. Possibilities include:

- $5 \%-10 \%$ of total revolving fund

- Savings: monthly contributions of about R5-10 would be allocated to the contingency fund; if unused, this will be savings by members

- Fund-raising activities, e.g. sales of products, beauty contests

- Profits from catering business could be allocated to contingency fund

- Charges of follow-up training if required.

It is also recommended that loan contracts should be standardised and made clearer to borrowers. It is essential that all terms and conditions of loans be systematically written into contracts, i.e. interest rate, loan maturity, repayment frequency, contingency fund, penalties for non-repayment, etc. Equally, individual borrowers should be provided with copies of their contracts, and any oral change should be reflected in written amendments to the existing contracts.

\subsubsection{Training}

Some innovations in training have been introduced recently; for example, peer auditing of book records and financial accounts whereby one participating community audits the books of 
another. In order to continue with this trend, it is recommended that FARM-SA initiate a pilot study to assess the value of further innovations which can lead to greater involvement of participants in skill-development.

One such new initiative is peer training or the training of ordinary members by trained fellow members - this appears more appropriate for financial management training. Another is the testing of ordinary members' skills (not just LB members) in situ on how to look after animals. In both cases, the idea is to set up a small group of willing participants and, in this way, pilot the value and success of those initiatives.

Simultaneously, possible incentive mechanisms for peer-training (e.g. "certificates" or formal recognition from FARM-SA) should be evaluated alongside the pilot study. Once evidence is gathered through this pilot study, FARM-SA can assess the usefulness of incorporating a larger scale of innovative training as suggested for the future of $L B s$ in Section 5.2.

\subsubsection{External finance}

During fieldwork, the research team undertook individual interviews with a number of institutions in order to identify potential sources for external finance into LBs. The major findings are:

- GWK Cooperative shows willingness to invest in LBs if suitable models are identified. At present, the GWK Cooperative is aware of FARM-Africa and there is already a degree of cooperation. Awareness about the needs of emerging farmers needs to be raised.

- Department of Agriculture suggests that the Food Security budget can be used for livestock. It has been said that this is a relatively small budget but it is suitable for livestock investment. Community projects would need to apply in accordance to budget cycles and set deadlines.

- MAFISA: This is a new funding source for microfinance schemes managed by the Department of Agriculture. Conceptually, it includes loans for livestock acquisition but it has not yet been piloted and hence it has not yet been finalised. However, it represents a significantly important potential source of support for LBs.

- Department of Agriculture, Livestock Improvement Programme. It was indicated that this programme plans to sell good-quality rams at book value, i.e. lower than market price and hence potentially beneficial to LB members.

- Land Bank: This commercial bank offers loans of up to R25,000 for poor households, no security required - it can be used for livestock purchase. Officials expressed their desire to continue their linkages with FARM-SA to firm up mutual collaboration in LB development.

- Given the aforementioned expressions of interest, it is strongly recommended that the programme follows up the possible areas of common interest and starts developing strategic relationships with these institutions in order to secure the sustainability and upscaling of Livestock Banks in the province.

\subsubsection{Promotion of LBs}

Related to the above, there is an immediate need to strengthen the advertising and promotion campaign of the LB model, current progress and future plans. Suggested options include: 
- Produce 1-2 page promotional leaflets

- Distribute them via print, website

- Disseminate information via radio, participation in forums at government, municipality and private organisations

- Participate in Department of Agriculture Project Co-ordination Committee meetings

- Formalise agreements with stakeholders at senior and middle management as well as at the grassroots levels.

\subsection{Medium- and longer-term recommendations}

For the medium and longer term, the research suggests a number of recommendations. These recommendations are essential for the planning of future activities in relation to Livestock Banks.

\subsubsection{Design}

Generally speaking, it is recommended that the original LB model be revised in order to speed up the process of productivity and achieve greater impact on beneficiaries' livelihoods. To this end, the stated aim of LBs should stress its productivity value rather than restricting it to the original aim of increasing ownership. In this way, both quality as well as quantity of stock is equally emphasised. The revised LB aim would be to:

- Enhance livestock productivity, i.e. quantity and quality of stock

- Create and increase productive assets amongst the poor members of land reform groups

- Act as the engine for the initiation of other income-generating activities

- Improve beneficiaries' livelihoods.

In unison with this new emphasis, it is proposed that revolving funds (i.e. seed capital provided by FARM-Africa to participating communities) be used in the purchase of one good-quality ram at the start of $L B$ establishment - in addition to the original 7 to 10 ewes per member. It should be recognised that to some extent this has been implemented in practice as mentioned in Section 3. However, this needs to be formally acknowledged as part of the model design and carefully studied for widespread implementation in all participating communities.

For cost-efficiency purposes, it is therefore advised that rams are acquired at the best price and in the best quality condition. Options are to: (1) Pursue a widespread process of donation by commercial farmers and other interested parties; (2) Establish formal agreement with breeder associations and the "Livestock Improvement Programme" of the Department of Agriculture the latter plans to sell good-quality livestock at prices below market levels; and (3) Purchase from reputable commercial sources that can guarantee quality although prices might be higher.

On the loan methodology, there is a need to formalise its hybrid quality, as there are benefits of encouraging high sense of ownership by individuals but also in promoting collective effort and participation. Thus, the methodology needs to be spelt out clearly to communities and potential beneficiaries:

- Individual responsibility for loans, i.e. contracts are signed with individuals 
- Livestock can be taken care of in communal or individual camps

- Group monitoring of animal care and hence assurance of prompt loan repayment by individuals.

In relation to the above and given existing difficulties in dealing with shepherds, it is recommended that the organising institution extends appropriate advice on how to manage shepherds, for example: (1) Introduce performance-related payments, e.g. basic salary plus bonus if animals are proven to be well looked after, and penalties if not; (2) Make shepherds beneficiaries of the LB; (3) Include them in institutional training of animal management; (4) Clearer contracts between the participating community and the shepherd; and (5) Salary should come from members' contributions if possible.

Another instrument to help increase the number of beneficiaries of LBs is through the formalisation of flexible loan repayment. In other words, it is recommended that beneficiaries across communities be allowed to repay their loans before the loan maturity is due, i.e. two years, if they so wish. This would allow a higher turnover of livestock and hence a larger number of beneficiaries of LBs.

Alongside flexible repayment, it is recommended that the programme explores the suitability of penalties for possible non-repayment of loans, monthly contribution, shepherd salaries, etc and try to standardise practices. Current options include: (1) $50 \%-100 \%$ fines for lack of monthly contribution; (2) Seizure of private animals if loan is not repaid; and (3) Participation in LB ends.

In relation to contingency funds mentioned before, voluntary savings could be promoted among beneficiaries. They could serve as (1) Part of the contingency fund; (2) Re-investment in the LB; (3) Investment in other productive activities, or (4) Simply to accumulate personal savings.

\subsubsection{Training}

Although existing training is well appreciated by beneficiaries, there is a tendency for it to be restricted to a relatively small number of total beneficiaries. This is a particular concern because the FARM-SA programme is designed to train beneficiaries mainly during the first year of their participation in the programme, while the following years are dedicated to monitoring and evaluation where training may or may not occur depending on identified needs. In other words, the first round of LB members benefit from full training but there is no complete guarantee that second-round (and other) members will receive similar comprehensive training.

In view of the above, it is recommended that the institution enhances ownership, spread and consolidation of knowledge by promoting full involvement of all programme members in the following manner.

\section{Financial management}

- Facilitate and monitor peer-training, within and across projects: i.e. the training of ordinary members by trained fellow members.

- Institute incentive mechanisms for peer-training: e.g. "certificates" or formal acknowledgement from FARM-SA, prizes, etc.

- Consider adapting manuals to different skill levels. 


\section{Animal and veld management}

- Establish follow-up assessment of knowledge: e.g. by in-situ testing of ordinary members' skills (not just LB members).

- Consider making it conditional for second-round LB beneficiaries to help first-round ones in looking after LB livestock.

- Request beneficiary associations' evidence of follow-up linkages with extension officers and cooperatives on training opportunities.

\subsubsection{Management structures}

There is also room for the simplification of management structures in order to ensure greater accountability and transparency. Options include to: (1) Consider merging the two existing subcommittees: Revolving Fund and Livestock Bank, or improve co-ordination between the two; (2) Promote sharing of financial information to all members; (3) Peer-training in financial management, and peer-auditing, whereby members of one project audit the financial accounts of another project; and (4) Promote regular elections of sub-committees.

\subsubsection{Further studies and field visits}

Similarly, there is a need for the production of three key basic studies, which may guide the development of an improved LB model and promote the initiation of other income-generating activities: (1) Economic study into the business viability of livestock production in the programme areas; (2) Market research into related income-generating activities; and (3) Impact study of existing projects, both Phase 1 and Phase 2.

Along similar lines, it would be advisable that the institution promotes field visits of staff to similar programmes worldwide, for example, FARM-Africa programmes in Tanzania, Ethiopia, and other neighbouring countries, Heifer programmes in Africa and similar international programmes in Africa and elsewhere. This would enable staff to familiarise themselves with the particular model designs and establish the pros and cons of implementing them in practice in specific contexts.

\section{Acknowledgement and disclaimer}

The author is grateful to FARM-Africa and FARM-Africa South Africa, a UK international organisation working for the sustainability of rural communities in Africa, for commissioning work in the Northern Cape and permitting the use of research findings in the preparation of this paper.

The FARM-Africa SA project was funded by the UK Department for International Development (DFID), Comic Relief, and the Belgium Embassy. The findings of the paper do not necessarily represent the views of FARMAfrica or any of the donors.

\section{REFERENCES}

Armendáriz de Aghion, B. \& Morduch, J. (2005). The Economics of Microfinance. USA: The MIT Press. 
Athmer, G., Ashton D. and Coleman M. (2003). Capacity building in community-based natural resource management, Mid-term review for FARM-Africa N Cape, South Africa \& FARM-Africa. London: FARM Africa.

Bradstock, A. (2005a). Key experiences of land reform in the Northern Cape province of South Africa. Policy \& Research Series. London: FARM-Africa.

Bradstock, A. (2005b). Supporting land reform in South Africa: Participatory planning experience in the Northern Cape province. Policy \& Research Series. London: FARM-Africa.

Bradstock, A. (2005c). Land reform and its impact on livelihoods: Evidence from eight land reform groups in the Northern Cape province of South Africa. Policy \& Research Series. London: FARMAfrica.

Brau, J. C. \& Woller, G. M. (2004). Microfinance: A Comprehensive Review of the Existing Literature. Journal of Entrepreneurial Finance and Business Ventures, 9(1), pp. 1-26.

Cull, R., Kunt, A. D. \& Morduch, J. (2007). Financial performance and outreach: A global analysis of lending microbanks. World Bank Policy Research. Washington D.C. USA: The World Bank.

FARM-Africa (2003). Northern Cape Land Reform and Advocacy Programme. London: FARM-Africa.

FARM-Africa (2006a). Northern Cape Land Reform \& Advocacy Programme (NCLRAP): Summary of Phase 2 projects to date. Institutional report. London: FARM-Africa.

FARM-Africa (2006b). Laughing Waters Farm Study. Institutional report. South Africa: FARM-Africa.

FARM-Africa (2006c). Ganspan Farm Study. Institutional report. South Africa: FARM-Africa.

FARM-Africa (2006d). Schmidtsdrift Farm Study. Institutional report. South Africa: FARM-Africa.

FARM-Africa (2006e). Lennertsville Farm Study. Institutional report. South Africa: FARM-Africa.

FARM-Africa (2006f). Brandvlei Farm Study. Institutional report. South Africa: FARM-Africa.

FARM-Africa (2006g). Baseline report: Phase 2.2 projects. Institutional report. South Africa: FARMAfrica.

Festus, H. \& Joseph L. (2006). Tracking the performance of livestock banks managed by land reform groups in the Northern Cape. South Africa: FARM-Africa.

Festus, H. \& Joseph, L. (eds.) (2007). Tracking the performance of livestock banks managed by land reform groups in the Northern Cape. Working Papers Series. Working Paper No. 5. South Africa: FARM-Africa.

Festus, H. (2006). Planning for Model Development: FARM-Africa. Power-point presentation, Kimberley, South Africa: FARM-Africa.

Hulme, D. \& Mosley, P. (1996). Finance Against Poverty. Volumes 1 and 2. London: Routledge.

Ledgerwood, J. (1999) Microfinance Handbook: An Institutional and Financial Perspective. Washington D.C.: The World Bank.

Marr, A. (2006). The limitations of group-based microfinance and ways to overcome them. Small Enterprise Development, 17(3), pp. 28-40.

Marr, A. (2003). A Challenge to the Orthodoxy Concerning Microfinance and Poverty Reduction. Journal of Microfinance, 5(2), pp. 7-42.

0xby, C. (1994) Restocking: A guide. VETAID. 
Marr

Pound, B. (2006). Final report on a support visit to the Land Reform and Advocacy Project, Northern Cape, South Africa. London: FARM-Africa.

Winpenny, J. T. (1991). Values for the environment: A guide to economic appraisal. London: HMSO. 